\title{
Developing a system to utilize a surveillance data for evidence- based public health interventions: Sleman HDSS's experience
}

\author{
Fatwa Sari Tetra Dewi ${ }^{1,2}$, Septi Kurnia Lestari' ${ }^{2}$, Hanifah Wulandari², Ibtidau Niamilah ${ }^{2}$ \\ ${ }^{1}$ Department of Health Behaviour, Environment, and Social Medicine, Faculty of Medicine, Public Health, and Nursing, \\ Universitas Gadjah Mada, Yogyakarta, Indonesia \\ 2Sleman Health and Demographic Surveillance System (HDSS), Faculty of Medicine, Public Health, and Nursing, \\ Universitas Gadjah Mada, Yogyakarta, Indonesia
}

KEYWORDS
Community
empowerment
Evidence-based
health intervention
HDSS
Health education
Population-based
data

KEYWORDS

ABSTRACT Health interventions aim to improve health status in a community. Factors that influence the effectiveness and success of intervention programs include the characteristics of problems and the target population. Sleman Health and Demographic Surveillance System (HDSS) collects data on demographics and public health status annually. By 2018, we have conducted four cycles of data collection from 5,147 households. Results from Sleman HDSS could provide important information regarding the characteristics of target populations and health-related problems they face. The present paper describes how we develop a system that uses the data from a surveillance system to inform the development of health intervention programs. Aside from collecting survey data, Sleman HDSS field staff also recorded statements from respondents and community leader regarding health issues which they thought needed to be addressed. We used both quantitative and qualitative information to identify problems and locations that should be the priority. This priority list then distributed to the academic communities in the Faculty of Medicine, Public Health and Nursing Universitas Gadjah Mada, (FMPHN-UGM) Yogyakarta, Indonesia. By 2018, we have completed 20 health educations and 10 community empowerment activities in collaboration with academic communities of the FMPHN-UGM. We concluded that health surveillance activities could support the development of effective evidence-based health intervention programs.

(c) The Journal 2020. This article is distributed under a Creative Commons Attribution-ShareAlike 4.0 International license.

\section{Introduction}

Indonesia faces multiple burdens of diseases, from infectious diseases and increasing prevalence of noncommunicable diseases. Therefore, effective and efficient intervention programs should be developed and implemented immediately. Prior to developing an intervention program several aspects need to be explored, such as the characteristics of the problems and the target groups, feasibility of the intervention types, proper implementation process, and evaluation procedures. ${ }^{1}$ This process highlights the importance of good quality data to support the early stages of an intervention program development.

Models of health intervention programs that use data as its core source of current information are also known as evidence-based public health

*Correspondence: hdssjogja.fkkmk@ugm.ac.id

Sleman Health and Demographic Surveillance System (HDSS) Faculty of Medicine, Public Health and Nursing, Universitas Gadjah Mada, Yogyakarta 55281, Indonesia interventions. In general, activities of development, implementation, and evaluation in evidence-based public health practice apply scientific reasoning with the latest in information technology. In this practice, data and information systems were used systematically. Behavioral science theory and program planning models were also utilized to support information derived from data. ${ }^{2}$ Evidence-based approaches have several benefits such as providing information on best practice options, increasing the potential of successful prevention programs and policies, and promoting human resource productivity and efficient use of public and private resources. ${ }^{3}$

The sources of data for evidence-based intervention programs may include research, peerreviewed research publications, and grey literature. ${ }^{4}$ Another important source of data is surveillance. Surveillance is the regular collection, analysis, use and sharing of data to prevent and control disease and injury. Surveillance systems usually track health 
problems such as both infectious and non-infectious diseases and health conditions, risk factors and exposures. ${ }^{5}$ As surveillance continuously collects data in the general population, it may provide a solid, reliable evidence on public health problems, the need for health intervention, and measures for the results of interventions. ${ }^{6}$

Indonesia has several national surveys (e.g. Riset Kesehatan Dasar/Indonesia Basic Health Survey -RISKESDAS and Program Indonesia SehatPendekatan Keluarga/Healthy Indonesia ProgramFamily Approach-PISPK) that could provide reliable evidence to mitigate public health problems even when the direct cause of a problem has not been identified, as showed historically by the cholera outbreak case in London in $1854 .^{7}$ However, the utilization of these data has not been optimal in district level.

Sleman Health and Demographic Surveillance System (HDSS) is a survey that monitors health and population conditions in the Sleman Regency, Yogyakarta Province, Indonesia since 2015 with the population of 5,147 households. Sleman HDSS provides qualified data on population health by conducting regular data collection on demographics, health problems, and health services. Demographic data collected includes information on migration, birth, death, causes of death and socio-economic data. While health-related data collected include infectious diseases, non-communicable diseases, reproductive health, maternal and child health, health behavior data and the use and accessibility of health services. ${ }^{8}$

We aimed to provide a practical example of survey data utilization to support evidence-based population health intervention. This paper describes the use of surveillance system data from Sleman HDSS, in the development of pilot evidence-based public health intervention activities.

\section{Methods}

Our evidence-based health intervention protocol was developed in accordance with the context, Sleman regency, and organizational culture in FMPHN-UGM. In this paper we explain every step in our protocol by comparing it with the guidelines to develop evidence- based health intervention programs proposed by the European Centre for Disease Prevention and Control, namely evidence cycle linked to the risk assessment process, (Fig. 1, column 2). ${ }^{9}$ Then we will discuss the feasibility of using PIS-PK data to design evidencebased health interventions.

The evidence cycle linked to the risk assessment process comprises several steps. First, preparatory information, in which the possible sources of valid data should be set up and the data gathered should regularly reviewed to develop evidence. In our case, the data source includes routine Sleman HDSS survey data and qualitative data from field team's notes. This qualitative data include information such as the description of physical environment, social relationships characteristics and health issues in Sleman HDSS' clusters. Our Interviewers and field supervisors use observation and interview methods to gather this data.

Second, in the risk detection and verification stage, the evidence is processed to detect potential problems. The quantitative data from Sleman HDSS survey was analyzed to gain information on the distributions of disease morbidity and other health conditions by sociodemographic status and region.

Third, the risk assessment stage includes identification of the priority health problems, its risk factors and the high-risk groups. In this stage, our experts derived a priority list from the qualitative and quantitative information. Fourth, the developing advice stage, experts review and weigh the evidence to advise on feasible interventions and its assessment tools. Guidelines are then developed accordingly. The next step is implementation then followed by monitoring and evaluation.

In this paper, we showed the example of qualitative data gathered between 2016-2018. However, only quantitative data from the 2017 (Release version 8-0-0) Sleman HDSS was used as the example. And thus, only the 2017 priority list example was presented.

\section{Results}

Figure 1 (column 1) depicts the process of evidencebased public health intervention in Sleman HDSS with the corresponding stage of evidence cycle linked to 


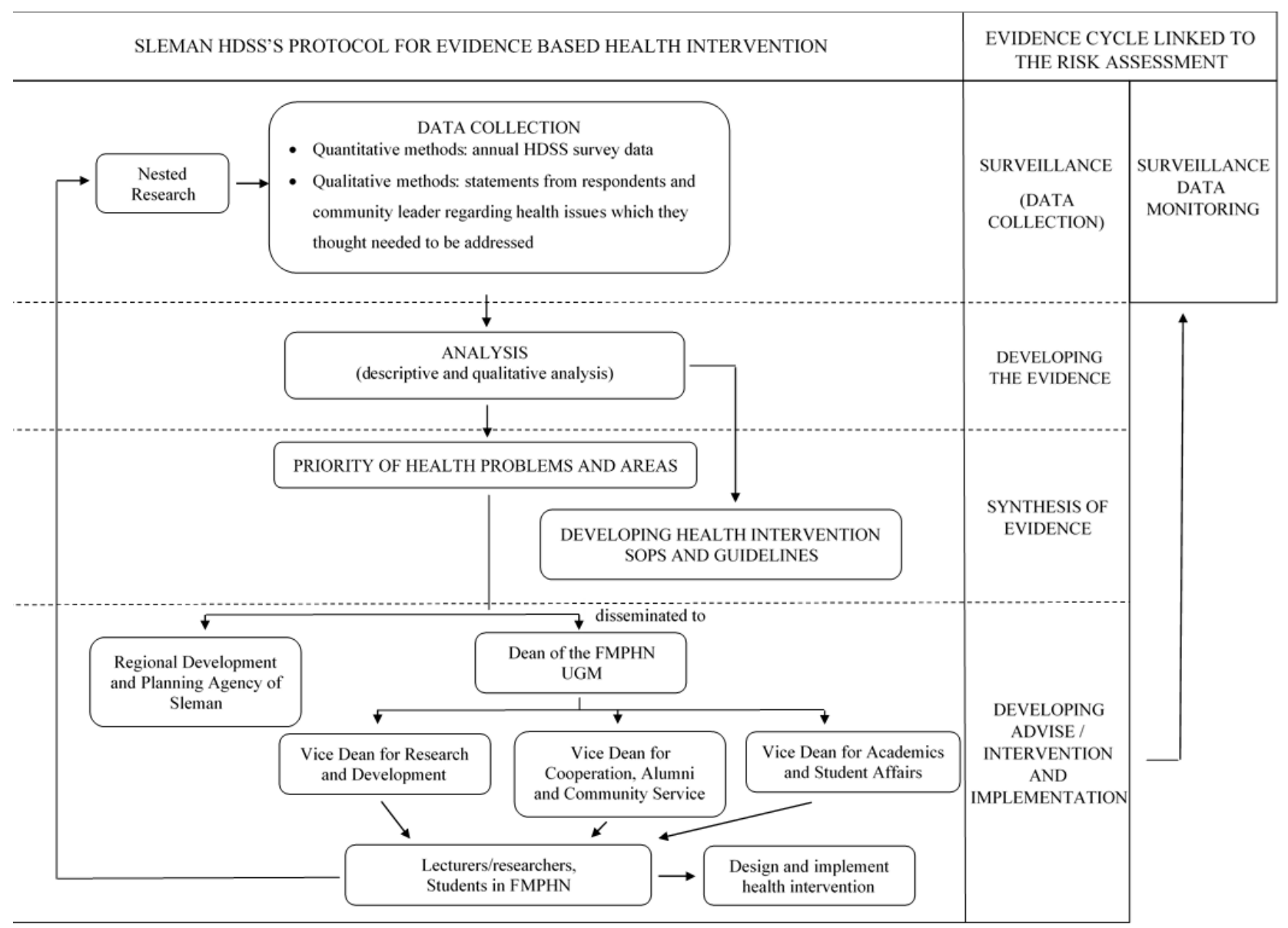

Figure 1. Evidence-based health intervention process in Sleman HDSS

the risk assessment process (Figure 1, column 2). The description of these steps is as follows: developing the evidence; synthesis of evidence; processing the demand to FMPHN system; and developing advice, intervention, and implementation.

\subsection{Developing the evidence}

\subsubsection{Quantitative data}

The Sleman HDSS Survey in 2017 found that the common education level of Sleman residents was the high school (35\%), while the main occupation was students (21\%), and the average age of first marriage was 22 years (women) and 25 years (men).

Data on utilization of health services and health insurance in 2015, 58.5\% of respondents reported ownership of health insurance, and this figure increased to $69 \%$ in 2017 and $77 \%$ in 2018 . Most of the respondents reported that they did not go to health facilities when they are sick $33.5 \%$ in
2016 and 26\% in 2017). Among respondents who went to see health practitioners, general physician practice was the main choice (19\% in 2016 and $25 \%$ in 2017). The main reason for not seeking treatment from health facilities was because they felt that their condition was not severe enough $(61 \%)$ or because they medicate themselves (25\%).

Figure 2 shows the main diseases of Sleman HDSS population in 2017. Compared to other diseases, Respiratory Infections (ARI) were the infectious disease with the highest prevalence, followed by dengue fever, tuberculosis, leptospirosis, and malaria. As for non-communicable disease, hypertension was the most common health condition reported by adults in Sleman.

To gain more insight on hypertension in this population, we assessed the respondents' sociodemographic characteristics by their hypertension status (Table 1). We found that hypertension was more common among people age 


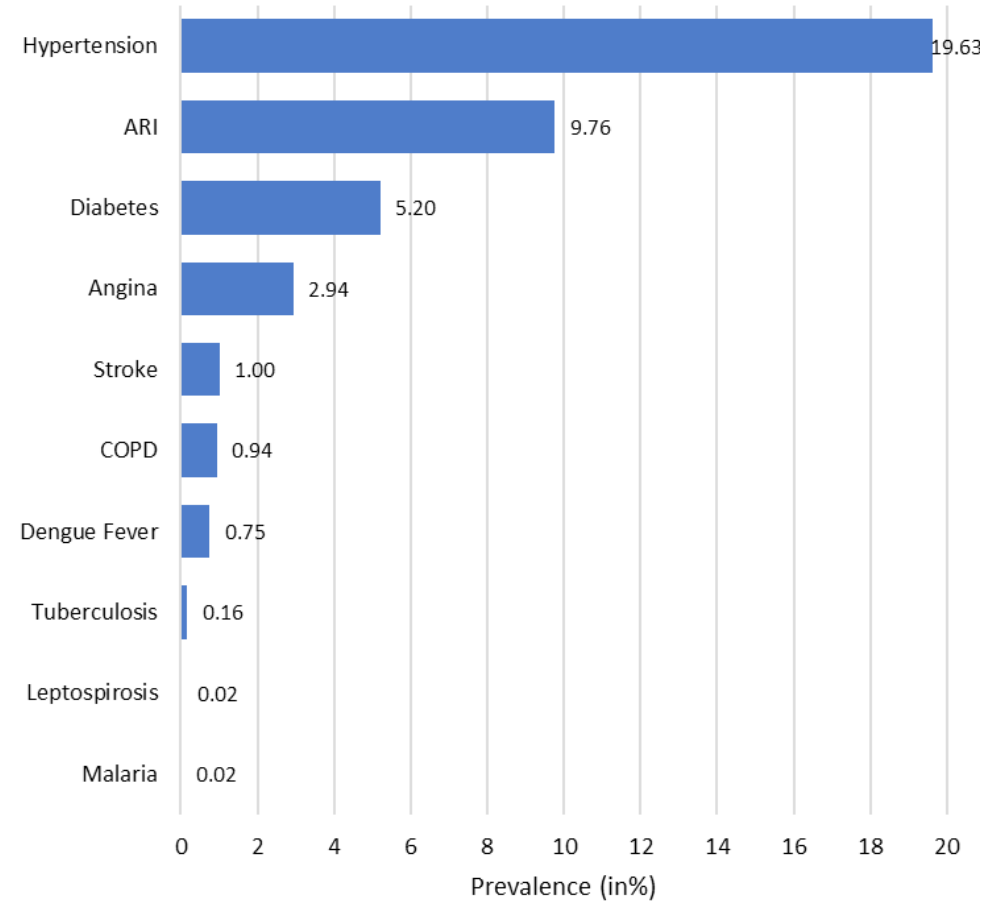

Figure 2. Prevalence of infectious and non-communicable diseases reported by respondents in Sleman HDSS in 2017. Note: We only collected data on most prevalent and most preventable diseases according to the District Health Office. Data on the prevalence of non-communicable diseases were obtained from sub populations, 1 person per households aged older than 25 years $(n=4,446)$; COPD= chronic obstructive pulmonary disease, ARI = acute respiratory infection; we obtain data on the prevalence of infectious diseases from the whole Sleman HDSS populations (all ages)

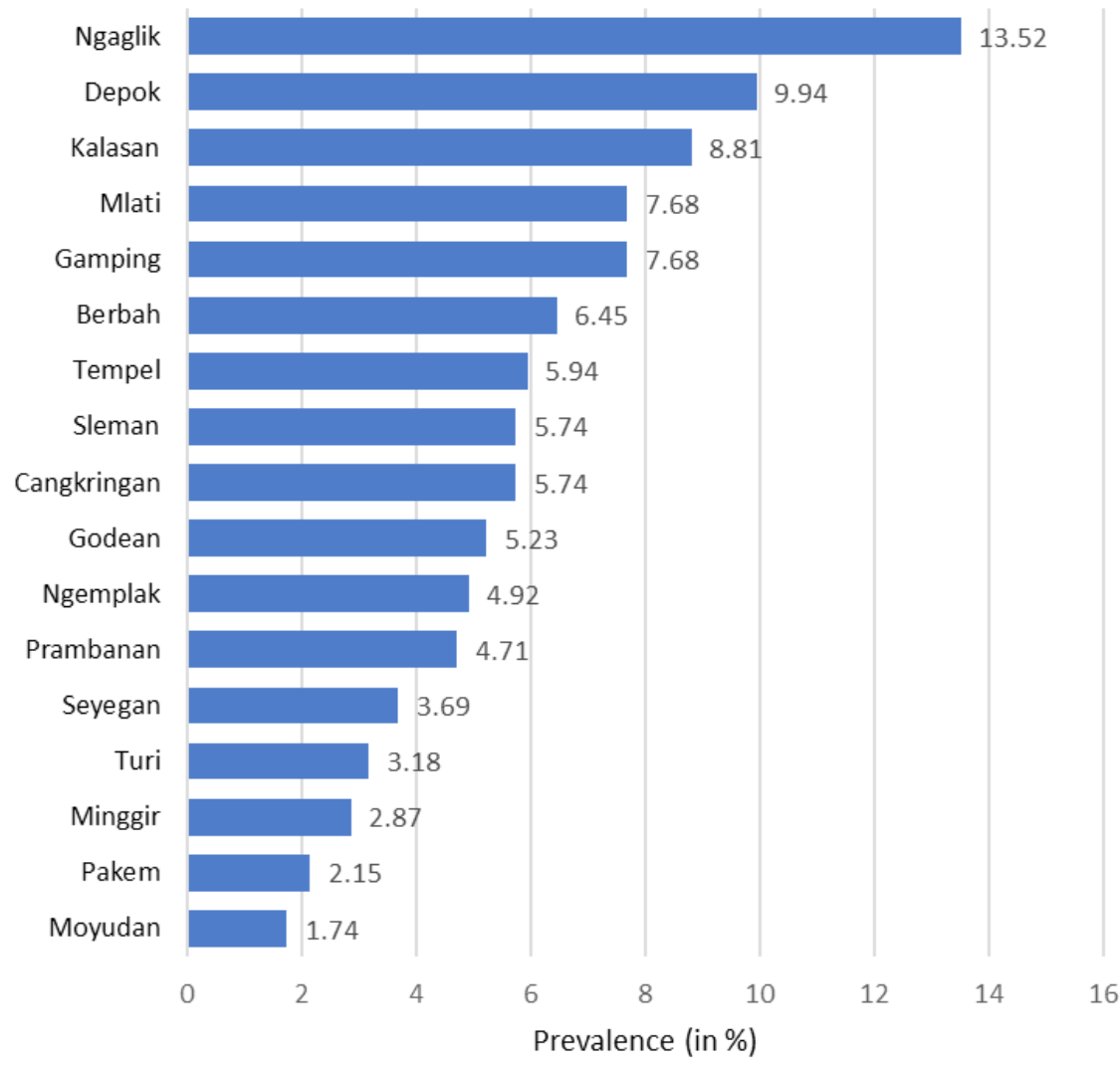

Figure 3. Prevalence of hypertension in Sleman HDSS' respondents aged 25+ years old by sub district in 2017 
Table 1. Respondents' characteristics by hypertension status in 2017

\begin{tabular}{|c|c|c|c|c|}
\hline & \multicolumn{2}{|c|}{$\begin{array}{l}\text { With } \\
\text { hypertension }\end{array}$} & \multicolumn{2}{|c|}{$\begin{array}{l}\text { Without } \\
\text { hypertension }\end{array}$} \\
\hline & $\mathrm{n}$ & $\%$ & $\mathrm{n}$ & $\%$ \\
\hline \multicolumn{5}{|l|}{ Age Groups } \\
\hline $25-34$ & 32 & 3.3 & 471 & 13.6 \\
\hline $35-44$ & 123 & 12.7 & 929 & 26.8 \\
\hline $45-54$ & 278 & 28.7 & 925 & 26.7 \\
\hline $55+$ & 535 & 55.3 & 1,145 & 33.0 \\
\hline \multicolumn{5}{|l|}{ Gender } \\
\hline Men & 340 & 34.8 & 1,565 & 44.4 \\
\hline Women & 636 & 65.2 & 1,961 & 55.6 \\
\hline \multicolumn{5}{|l|}{ Marital status } \\
\hline Single & 233 & 23.9 & 680 & 19.3 \\
\hline Married & 742 & 76.1 & 2,846 & 80.7 \\
\hline \multicolumn{5}{|l|}{ Education level } \\
\hline Low & 355 & 36.6 & 1,018 & 29.0 \\
\hline Middle & 483 & 49.9 & 1,927 & 54.9 \\
\hline High & 131 & 13.5 & 565 & 16.1 \\
\hline \multicolumn{5}{|l|}{$\begin{array}{l}\text { Household wealth } \\
\text { index }\end{array}$} \\
\hline Q1 & 206 & 21.1 & 703 & 19.9 \\
\hline Q2 & 200 & 20.5 & 736 & 20.9 \\
\hline Q3 & 176 & 18.0 & 677 & 19.2 \\
\hline Q4 & 202 & 20.7 & 700 & 19.9 \\
\hline Q5 (Richest) & 192 & 19.7 & 710 & 20.1 \\
\hline $\begin{array}{l}\text { Health insurance } \\
\text { ownership }\end{array}$ & 758 & 78.3 & 2,569 & 73.3 \\
\hline
\end{tabular}

$55+$, were women, single, and had low education level. Analysis at the sub-district level (Figure 3) revealed that Ngaglik, Depok, and Kalasan may need immediate intervention as the prevalence of hypertension was the highest in those sub-districts. In practice, other health problems were also explored and were considered in determining the priority list.

\subsubsection{Qualitative data}

Table 2 presents several of the health problems that our respondents were concerns about. Most of these statements corresponded to the results of quantitative data analysis, such as those concerning NCDs and the tendency of citizens to choose selfmedication when sick. In addition, residents also raised other health issues, such as skin health and food security.

\subsection{Synthesis of evidence}

\subsubsection{Developing health problem priority list}

Sleman HDSS' division of community engagement conducted meetings between researchers and experts in health promotion to derive a priority list from the results of quantitative and qualitative data analysis. As examples, we present the priority list in 2017 (Table 3).

The list of health problems (Table 3) was then reported to the FMPHN Dean who was then being delegated to the Vice Dean of Academic and Student Affairs, the Vice Dean of Cooperation, Alumni and Community Service and the Vice Dean of Research and Development.

\subsection{Processing the demand to FMPHN system}

\subsubsection{Gaining further information through nested research}

The Vice Dean of Research and Development offered the priority list of health-related problems in the Sleman HDSS areas to lecturers and students as a potential topic for further research. They can perform secondary data analysis of Sleman HDSS data to gain more insights into the priority problems. Furthermore, they can collect additional information from Sleman HDSS respondents through nested research scheme in Sleman HDSS. Doing so will deepen their analysis and understanding of problems they are interested in.

A total of 14 nested researches have been conducted in Sleman HDSS area between 20152018 (data not shown). Several topics covered by nested research were NCDs, death events, maternal and child nutrition, elderly health, dental health, and healthy city modeling. Most of those nested researches received a grant from FMPHN UGM. Findings from secondary data analysis and nested research enrich the main findings from Sleman HDSS which then will also improve our evidence-based public health interventions.

\subsection{Developing advice, intervention and implementation}

3.4.1 Implementing evidence-based health intervention program through teaching activities

Master students from School of Public Health in Health Promotion Major carried out community 
Table 2. Examples of qualitative data on health problems reported by the community in 2017

\begin{tabular}{|c|c|}
\hline $\begin{array}{l}\text { Locations } \\
\text { (sub-village, village, Sub-district) }\end{array}$ & Identified problem from respondents and field staff notes \\
\hline Pundong 2, Tirtoadi, Mlati & $\begin{array}{l}\text { Some residents prefer to buy their own medicine without a doctor's } \\
\text { prescription, use drugs that are still available from previous examinations. } \\
\text { They tend to pay little attention to drugs storage and expiration date. } \\
\text { Smoking and low physical activity were common in the community. Majority of } \\
\text { respondents are available in the afternoon. }\end{array}$ \\
\hline Pundong 1, Tirtoadi, Mlati & $\begin{array}{l}\text { Lack of knowledge about HIV / AIDS. Houses are close to each other. Most feasible } \\
\text { time for visits is in the afternoon. }\end{array}$ \\
\hline Candiwinangun, Sardonoharjo, Ngaglik & $\begin{array}{l}\text { Respondents want to know about skin diseases and how to prevent them. Also, } \\
\text { regarding hygiene and healthy lifestyle. Residents and the community leader are } \\
\text { very cooperative. }\end{array}$ \\
\hline Karang Malang, Catur Tunggal, Depok & $\begin{array}{l}\text { Lack of knowledge about non-communicable diseases among the older adults. High } \\
\text { density housing, residents very cooperative, there is a well-manage POSYANDU } \\
\text { Lansia (integrated health post for older adults) with a high participation rate. }\end{array}$ \\
\hline Mrican, Catur Tunggal, Depok & $\begin{array}{l}\text { Residents wanted to know about reproductive health, especially related to } \\
\text { cervical cancer. }\end{array}$ \\
\hline Samirono, Catur Tunggal, Depok & $\begin{array}{l}\text { Residents were aware that hypertension and diabetes were a common health } \\
\text { problem in their community. Cadres of POSYANDU Lansia felt that they had } \\
\text { limited ability in performing their tasks. }\end{array}$ \\
\hline Nglaban, Sinduharjo, Ngaglik & $\begin{array}{l}\text { Residents were concern about the high number of hypertension cases in their } \\
\text { community, especially among the older adults. Low participation of older adults } \\
\text { in POSYANDU Lansia. }\end{array}$ \\
\hline
\end{tabular}

Table 3. Example of health problems priority list in 2017

\begin{tabular}{ll}
\hline Location & Description of the health problem \\
\hline Catur tunggal, Depok & $\begin{array}{l}\text { High prevalence of hypertension and diabetes mellitus. Require intervention } \\
\text { programme to increase awareness about NCDs and preventing NCDs' risk factors. } \\
\text { Rundong 2, Tirtoadi, Mlati }\end{array}$ \\
Require health education regarding the danger of self-medication. \\
Require health education to increase the correct understanding about HIV/AIDS \\
Sinduharjo, Ngaglik & $\begin{array}{l}\text { Require intervention programme to address the high prevalence of hypertension } \\
\text { and the low participation in POSYANDU Lansia }\end{array}$ \\
Sardonoharjo, Ngaglik & $\begin{array}{l}\text { Needs health education regarding personal hygiene. } \\
\text { Needs health education regrading reproductive health with more focus on } \\
\text { Mrican, Catur Tunggal, Depok }\end{array}$ \\
\hline
\end{tabular}

empowerment activities in Sleman HDSS' area as their compulsory practical assignment of community empowerment and networking course. In these community empowerment activities, masters students with the local residents of Sleman HDSS area worked together to solve the health-related problems in their neighborhood. By taking part in all development an implementation steps of community empowerment activities, the residents were expected to be able to manage and improve the programs implemented by themselves. ${ }^{10}$

Residents from various age groups and organizations involved in problem identification, planning, implementation, and program evaluation.
In problem identification stage, master students shared the findings from Sleman HDSS, and the residents were asked to share their thoughts on health-related problems in their community. Through several discussions, the main theme and intervention activities were decided. Table 4 presents the summary of community empowerment activities conducted between 2016-2018, the more detail information regarding each community empowerment activity are available in Sleman HDSS website (https://hdss. fk.ugm.ac.id/).

\subsubsection{Implementing evidence-based health intervention program through community service activities}


Table 4.Community empowerment projects conducted in 2016-2018

\begin{tabular}{|c|c|c|}
\hline Date & Place & Project Title \\
\hline July-October 2016 & Sembung, Purwobinangun, Pakem & $\begin{array}{l}\text { Child jumantik (larvae surveyors) to prevent } \\
\text { dengue fever }\end{array}$ \\
\hline March-October 2016 & Bedoyo, Wukirsari, Cangkringan & $\begin{array}{l}\text { Dengue fever prevention by implementing } \\
\text { Community-based Total Sanitation programme }\end{array}$ \\
\hline September-October 2017 & Sembung, Purwobinangun, Pakem & $\begin{array}{l}\text { Health cadre's capacity building to improve } \\
\text { services in POSYANDU Balita (Integrated health } \\
\text { service for under-five children) }\end{array}$ \\
\hline September-October 2017 & Nglaban, Sinduharjo, Ngaglik & $\begin{array}{l}\text { Preventing hypertension through healthy diets } \\
\text { and increase older adults' participation in } \\
\text { POSYANDU Lansia }\end{array}$ \\
\hline September-October 2017 & Samirono, Catur Tunggal, Depok & $\begin{array}{l}\text { Health cadre's capacity building to prevent non- } \\
\text { communicable diseases' risk factors }\end{array}$ \\
\hline September-October 2017 & Pundong 2, Tirtoadi, Mlati & Community' actions to prevent hypertension \\
\hline March-September 2018 & Sembung, Purwobinangun, Pakem & Healthy joints, NCDs gone \\
\hline March-September 2018 & Nglaban, Sinduharjo, Ngaglik & $\begin{array}{l}\text { Health cadre's capacity building to maintain } \\
\text { older adults' health }\end{array}$ \\
\hline March-September 2018 & Pundong, Tirtoadi, Mlati & Health promotion in Pundong II \\
\hline March-September 2018 & Jaten, Sendangadi, Mlati & School for Jaten's health cadre \\
\hline
\end{tabular}

Table 5. Health educations conducted in 2016-2018

\begin{tabular}{|c|c|c|}
\hline Date & Place & Theme \\
\hline April 2016 & Nglaban, Sinduharjo, Ngaglik & Stroke prevention \\
\hline May 2016 & Pundong 2, Tirtoadi, Mlati & Children's oral hygiene \\
\hline May 2016 & Krapyak, Margoagung, Seyegan & Food nutrition and safety \\
\hline May 2016 & $\begin{array}{l}\text { Jengkelingan and Putrowangsan, Sidoarum, } \\
\text { Godean }\end{array}$ & Personal hygiene \\
\hline June 2016 & Kopen Becici, Wonokerto, Turi & Hypertension prevention \\
\hline August 2016 & Kuningan, Karangmalang, Catur Tunggal, Depok & Dementia \\
\hline August 2016 & Kuningan, Karangmalang, Catur Tunggal, Depok & Non-communicable diseases risks screening \\
\hline August 2016 & Kuningan, Karangmalang, Catur Tunggal, Depok & Non-communicable diseases prevention \\
\hline April 2017 & Kajor, Nogotirto, Gamping & Skin health and cosmetics safety \\
\hline April 2017 & Pundong 2, Tirtoadi, Mlati & Self-medication \\
\hline May 2017 & Candiwinangun, Sardonoharjo, Ngaglik & Personal hygiene and health \\
\hline May 2017 & Sekarsuli, Sendangtirto, Berbah & Stroke prevention and care \\
\hline July 2017 & Pundong 1, Tirtoadi, Mlati & HIV/AIDS \\
\hline August 2017 & Karangmalang, Catur Tunggal, Depok & Older adult's health \\
\hline September 2017 & Mrican, Catur Tunggal, Depok & Reproductive health \\
\hline May 2018 & Pangukan, Tridadi, Sleman & Health during Ramadhan \\
\hline May 2018 & Candi winangun, Sardonoharjo, Ngaglik & Health during Ramadhan \\
\hline July 2018 & Kentungan, Condongcatur, Depok & Older adult's oral hygiene \\
\hline August 2018 & Kuningan, Karangmalang, Catur Tunggal, Depok & Older adult's health \\
\hline
\end{tabular}

Under the Vice Dean of Cooperation, Alumni and Community Service the priority list were offered as potential issues that lecturers can address through community service as part of their Tri Dharma obligations. Sleman HDSS also directly invited lectures to join community service activities managed by
HDSS' division of community engagement. Lecturers have liberty to design the intervention programs according to their expertise. During the intervention program development, Sleman HDSS team helps in obtaining permission from the local leaders, arranging schedule, and other administrative requirements. By 
the end of 2018, there have been 20 health education activities by lecturers and students of UGM (Table 5).

\subsubsection{Utilization of data for intervention by the government}

Every year, we present the results of quantitative data analysis to Sleman BAPPEDA and other related agencies, such as the Health Office, Sleman Hospital, Prambanan Hospital, Social Service, P3AP2KB Office (Women's Empowerment and Child Protection, Population and Family Planning Control). These governmental agencies used Sleman HDSS data in evaluating their programs in the previous period. Also, in creating the next period development planning, these agencies take into account the information from Sleman HDSS aside from the routine register data they own. Through this activity, Sleman HDSS promotes the importance of population health survey data in planning and evaluating government intervention programs.

\section{Discussion}

Results from quantitative data analysis on Sleman HDSS survey data revealed that Sleman Regency is facing an epidemiological transition, where increasing non-communicable diseases (NCDs) is a major health problem, but on the other hand, infectious diseases have not been well addressed. Even the condition of the epidemiological transition in Sleman was seen earlier than other regions in Indonesia. One of the factors supporting this is Sleman Regency's higher life expectancy than the national rate $(82.85$ years compared to 70.81 years). ${ }^{11}$ The high life expectancy results in an increase in the proportion of the elderly population accompanied by an increase in the prevalence of NCDs. ${ }^{12}$ RISKESDAS 2013 showed that Sleman Regency has the highest prevalence of diabetes mellitus and cancer in Indonesia. ${ }^{13,14}$

In the present paper, we described how we used the population survey data in the designing of evidence-based public health intervention programs. The protocol we developed was generally in line with guidelines to develop evidence-based health intervention programs, namely evidence cycle linked to the risk assessment process, by The European Centre for Disease Prevention and Control (Fig. 1). We present example qualitative data analysis that focused on hypertension. But as showed in Table 3 and Table 4, the intervention activities also addressed other health issues. Some of those issues were mainly based on qualitative information from respondents and community leaders. We acknowledge that qualitative data enriched the information we got from quantitative data.

Quantitative data provides information about the magnitude of health problems, where and when it occurs and what are the characteristics of the people who are impacted by that health problems. While qualitative data provides an understanding of why and how a social phenomenon occurs in the community and public concerns related to health problems and their potential solutions. ${ }^{15}$ In practice, qualitative information was very important in deciding the targeted group and the type of health intervention activity.

Other important lessons learned from Sleman HDSS experience are the importance of integration with the existing system and cooperation across disciplines. Sleman HDSS disseminates the list of priority health problems, through the UGM Vice Dean's office to ensure that most of the lecturers and students receive this information. In the implementation stage, to increase participation health intervention activities organized by Sleman HDSS usually are integrated with the regular activities in the community. The health-related problems emerged from HDSS data are diverse. It often requires experts not only from within FMPHN UGM but also from other faculties. As currently there are no established protocols to disseminate the list of health problems to other faculties, Sleman HDSS staff directly contact the experts from other FMPHN faculties when needed.

\section{PIS-PK data to design evidence-based health interventions}

Sleman HDSS' experiences in using surveillance data for evidence-based intervention programs development show that other surveillance data in Indonesia also have potential in providing evidence. Healthy Indonesia Program with Family approach (Program Indonesia Sehat-Pendekatan Keluarga/ PIS-PK) is one survey with this potential. PIS-PK 
priority programs include: 1) reducing maternal and infant mortality, 2) improving child nutrition status especially stunting, 3 ) eradicating infectious diseases, especially HIV, tuberculosis and malaria, and 4) controlling NCDs such as hypertension, diabetes, obesity, mental disorders, and cancer.

PIS-PK team, usually PUSKESMAS doctors and nurse, visits every household in their PUSKESMAS working area. They collect data on family health profiles and perform preventive activity (e.g. health education) and curative-related activities. ${ }^{16}$ The survey part of PIS-PK collects data covering the healthy family's 12 indicators. They store and update this data in PUSKESMAS' family database. PIS-PK has a data pooling system to compile all data from PUSKESMAS to the Health offices in regency level, province level, and national level in The Health Ministry office. Currently, data from PIS-PK is mainly used to inform Healthy Life Movement (Gerakan Masyarakat Hidup Sehat-GERMAS) and to produce health indicators such as Healthy Individual Indicators (Indikator Individu Sehat /IIS), Healthy Family Index (Indeks Keluarga Sehat /IKS), Healthy Community Indicators (Indikator Masyarakat Sehat / IMS), Healthy Villages / Districts, Healthy Districts / Cities, Healthy Provinces, and Healthy Indonesia. ${ }^{17}$

PIS-PK data are very rich and dynamic. If it is managed and analyzed properly, relevant stakeholders can use PIS-PK data to design effective and efficient health intervention programs. ${ }^{18}$ Similar to surveillance data, as PIS-PK collects data continuously, it may also capture the effect of health intervention programs implemented before the current survey.

Sleman HDSS also has demonstrated that the use of mixed methods (quantitative and qualitative data) results in gaining a better understanding of what the target population needs thus improving the adoption of the health programs. ${ }^{19}$ The field of public health has long been dominated by positivistic (quantitative) approaches to prove the existence of health problems (what, where, who and when), but has a weakness to understand why and how social phenomena such as people in communities behave in a certain way related to health problems. An understanding of why and how on a social phenomenon becomes very important in tackling NCDs- related problems as they are closely associated with social problems. The shift in the need for this approach calls for a shift in epidemiology to social epidemiology. Academics and stakeholders in the public health field need to understand the importance and perform mixed methods research to improve health intervention programs. ${ }^{20}$

Besides home visits for data collection, PIS-PK also organizes several activities to maintain a good rapport with the communities in their working area. Those activities include focus group discussion for a dasawisma (a group of 10 households who live in the same area), and health counseling in forums that already exist in the community. ${ }^{17}$ These activities have the potential to become another means to collect qualitative data to enrich PIS-PK survey data.

\section{Conclusion}

Surveillance data and could provide valuable information on the burden of diseases in a population. In Sleman HDSS, both infectious, such as respiratory infection, and non-communicable diseases, such as hypertension and diabetes mellitus, were prevalent. We showed that qualitative data was as valuable as quantitative data in designing effective public health intervention programs. This approach can also be implemented by using data from PIS-PK. Considering the importance of qualitative research, we encourage PIS-PK to collect qualitative data as well as quantitative data to be combined with HDSS related findings.

\section{Acknowledgement}

This manuscript utilizes data from HDSS Sleman (Rel 8-0-0) with the main funding from the Faculty of Medicine, Public Health and Nursing, Gadjah Mada University, Yogyakarta, Indonesia.

\section{Conflict of interest}

There is no conflict of interest.

\section{References}

1. Bartholomew LK, Parcel GS, Kok G, Gottlieb $\mathrm{NH}$. Planning Health Promotion Programs: An 
intervention mapping program. 2nd edition. San Francisco: Jossey-Bass A Wiley Imprint; 2006.

2. Department of Health and Human Services. Evidence-Based Clinical and Public Health: Generating and Applying the Evidence. Secretary's Advisory Committee on National Health Promotion and Disease Prevention Objectives for 2020; 2010.

3. Vanagas G, Bala M, Lhachimi SK. Editorial: Evidence-based public health 2017. Biomed Res Int. 2017;1-2.

4. Jamison DT, Breman JG, Measham AR, Alleyne G, Claeson M, Evans DB, et al. Disease control priorities in developing countries, 2nd edition. Washington (DC): The International Bank for Reconstruction and Development/The World Bank; New York: Oxford University Press. 2006. Chapter 53: Public health surveillance : a tool for targeting and monitoring interventions; p. 9971015.

5. Office of Public Health Scientific Service. CDC Public Health Surveillance Strategy Report: 2014-2018. Atlanta, GA: Centers for Disease Control and Prevention; 2018.

6. Rein DB. economic and policy justification for public health surveillance in Principles and Practice of Public Health Surveillance. In: Lee LM, Teutsch SM, Thacker SB, St. Louis ME, editors. Principles and Practice of Public Health Surveillance. 3rd ed. New York: Oxford University Press; 2010.

7. Gordis L. Epidemiology. 5th. Canada: Elsevier Saunders; 2014.

8. Dewi FST, Choiriyyah I, Indriyani C, Wahab A, Lazuardi L, Nugroho A, et al. Designing and collecting data for a longitudinal study: the Sleman Health and Demographic Surveillance System (HDSS). Scand J Public Health. 2017; 46(7):704-710

9. European Centre for Disease Prevention and Control. ECDC technical report: evidence-based methodologies for public health. 2011. 1-67 p.

10. Tetra Dewi FS, Stenlund $H$, Marlinawati VU, Öhman A, Weinehall L. A community intervention for behaviour modification: an experience to control cardiovascular diseases in Yogyakarta, Indonesia. BMC Public Health [Internet].
2013;13(1):1043.

11. Badan Pusat Statistik. Indeks Pembangunan Manusia menurut Kota atau Kabupaten tahun 2017 [Internet]. 2017. Available from: https://www. bps.go.id/dynamictable/2018/04/16/1297/ indeks-pembangunan-manusia-menurutkabupaten-kota-2017-metode-baru-.html

12. Rechel B, Doyle Y, Grundy E, Mckee M. How can health systems respond to population ageing ? WHO Eur [Internet]. 2009;43. Available from: http://www.euro.who.int/__data/assets/pdf_ file/0004/64966/E92560.pdf

13. Sugianto, Fauzan $M$, Setyai $A$, Prihatini $M$. Riskesdas dalam Angka Provinsi DIY Tahun 2013. Jakarta: Lembaga Penerbitan Badan Litbangkes; 2013. 293 p.

14. Kementrian Kesehatan Republik Indonesia. Riset Kesehatan Dasar (RISKESDAS) 2013. Jakarta: Badan penelitian dan pengembangan kesehatan; 2013.303p.

15. Creswell JW. A concise introduction to mixed methods research. United States: SAGE Publication, Inc; 2015.

16. Kementerian Kesehatan Republik Indonesia. Pedoman Umum Program Indonesia Sehat Dengan Pendekatan Keluarga. Jakarta: Kementerian Kesehatan RI; 2016.

17. Kementerian Kesehatan Republik Indonesia. Petunjuk Teknis Penguatan Manajemen Puskesmas Dengan Pendekatan Keluarga. Jakarta: Kementerian Kesehatan Rl; 2016.

18. Matarrita-Cascante D, Brennan MA. Conceptualizing community development in the twenty-first century. Community Dev. 2012; 43(3):293-305.

19. Noyes J, Booth A, Moore G, Flemming K, Tunçalp Ö, Shakibazadeh E. Synthesising quantitative and qualitative evidence to inform guidelines on complex interventions: clarifying the purposes, designs and outlining some methods. BMJ Glob Heal. 2019; 4 (Suppl 1):e000893.

20. Kaur M. Application of mixed method approach in public health research. Indian J Community Med. 2016; 41(2):93-7. 